\title{
Was the Austro-Hungarian Monarchy One of the True Great Powers? \\ On the Historical-Geographical and Political-Geographical Aspects of the Fall of the Austro-Hungarian Monarchy
}

\section{Mihály Miklós NAGY - László GULYÁS}

\author{
Földrajzi Intézet, Pécsi Tudományegyetem, Institute of Geography, University of Pécs, \\ Ifjuság útja 6, 7622 Pécs, Hungary \\ nagyvazul@freemail.hu \\ Ökonómia és Vidékfejlesztési Intézet, Szegedi Tudományegyetem, Institute of economy and rural \\ development, University of Szeged, Mars-tér 7, 6727 Szeged, Hungary \\ gulyas1@t-online.hu
}

\section{Shift to the East: the 'Historical Line"}

The spatial structure of the Austro-Hungarian Monarchy, a state born in 1867, was the end-product of a process of spatial development that had lasted several centuries. This process can best be described by summing up the spatial changes of Habsburg-owned properties in the given historical periods. ${ }^{1}$

The oldest property of the Habsburg dynasty - the castle of Habichtsburg - is located in the Swiss canton of Aargau. In the 13-14 $4^{\text {th }}$ centuries, the Habsburgs' Central European possessions were still of insignificant size, but, by the turn of the $15-16^{\text {th }}$ centuries the members of the dynasty succeeded in acquiring the throne of Spain and, at the same time, they got hold of huge possessions both in Europe and overseas. They could only keep control over this situation of sudden growth by dividing the dynasty into two - Spanish and Austrian - branches. The Spanish branch reigned over Portugal, Spain, The Netherlands, Burgundy, the Kingdom of Naples, the Kingdom of Sardinia, Sicily and the colonies overseas. In comparison, the Austrian branch at that time was of less significance. This situation changed radically after the War of the Spanish Succession (1701-1714): the Spanish branch of the Habsburg dynasty died out and thus the Habsburgs lost not only their lberian kingdom but also most of their colonies overseas. This is why the centre of the Habsburg Empire shifted to the East, i.e. to the Danube Valley. ${ }^{2}$

From this time on, the Austrian branch of the Habsburg dynasty, which had only played a secondary role formerly, moved into the foreground in history. In the $18-19^{\text {th }}$ centuries, their possessions gradually shifted to the East. This process meant that the Austrian branch lost several provinces in the 'West' - i.e. in the Western half of Europe - including Austrian Netherlands, Milan, Parma, the Kingdom of Sardinia, the Kingdom of Sicily and the Province of Silesia. At the same time the Habsburgs acquired the new provinces of Galicia and Bukovina (1772-1795) in the East. When summarizing all these changes, it can be stated

1 Imre GONDA - Emil NIEDERHAUSER, A Habsburgok, Egy európai jelenség, Budapest 1977, 40-41, 216217, 120-121; Harold STEINACKER, Auswirkungen des Raumes in der österreichischen Geschichte, in: Harold STEINACKER, Austro-Hungarica, Ausgewählte Aufsätze und Vorträge zur Geschichte Ungarns und der österreichisch-ungarischen Monarchie, München 1963, 176-185.

2 Ferenc SZÁVAI, Az Osztrák-Magyar Monarchia felbomlásának következményei, Pécs 2004, 22. 
that they definitely meant a shift to the East. By the late $18^{\text {th }}$ century, it had become obvious that the Eastern Habsburg Empire located by the Danube, was already in the process of making.

This trend continued throughout the first half of the $19^{\text {th }}$ century. Since the monarchs of the Austrian branch of the Habsburg dynasty bore the title of Holy Roman Emperors and the Holy Roman Empire legally ceased to exist in the period of the Napoleonic Wars (1806), in order to replace this tradition, Francis I of the Habsburg Dynasty became the Emperor of Austria in 1804. This new title signalled the emergence of a new Habsburg Empire in the Danube Valley. ${ }^{3}$ From a geographical point of view, it meant that the possessions of the Habsburg monarchs were concentrated in one large contiguous area, with the Danube being the most decisive geographical feature of the spatial unity, connecting the area's individual parts. In the opinion of a significant number of political geographers, the River Danube was the most significant connecting link within the Habsburg Empire. ${ }^{4}$ These academics build their theory upon the fact that rivers - as natural transport routes - have always been connecting areas of different characteristics. When consulting the map, it becomes obvious that it was the River Danube that bound together all the significant areas within the Monarchy.

The next step in the shifting process is represented by the birth of the unified Italian and German nation-states. When the Italian nation-state came into being, it also meant that the Habsburgs lost their former provinces in Northern and Central Italy including Lombardy, Venice, Parma, Modena and Tuscany. Owing to the Habsburgs' defeat in the Austrian -Prussian War in 1866, the unification process in Germany was led by Prussia. Thus, the Habsburgs had to give up all their plans on further westward expansion. Instead, with the birth of the Austro-Hungarian Monarchy in 1867, the Monarchy included areas in Central Europe, in and near the Danube Valley.

The Monarchy's shift to the East continued after 1867. Due to the weakening of the Ottoman Empire as well as to the struggle for national independence on the Balkans, in 1878 the Austro-Hungarian Monarchy invaded Bosnia-Herzegovina, then, three decades later, in 1908 it annexed the territory. ${ }^{5}$

The so-called politics of 'territorial balancing', a well-known process in geopolitics and, at the same time, a characteristic feature of the Monarchy, can also be linked to the formerly described shift to the east. The theoretical basis of territorial balancing is the idea that in case an empire loses territories due to military defeat, it may compensate itself for the loss by expanding in another direction. The best example of this politics is the Habsburg Monarchy of the Danube Valley. As it is described in geopolitical specialist literature, after

3 Tamás László VIZI, Die politische Rolle des ungarischen Adels im Zeitalter der französischen Kriege, in: Zusammenfassung der Beitrage zum Napoleon Symposium „Feldzug 1809” im Heeresgeschichtlichen Museum Wien, 4. und 5. Juni 2009, R. Ouvrard - F. I. Wöber (eds.), Wien 2009, 112-119; Tamás László VIZI, Magyarország és a francia háborúk, in: Franciák Magyarországon, 1809. Konferencia II, József Bana - Csaba Katona (eds.), Budapest - Györ 2012, 261-277.

4 Friedrich RATZEL, A Föld és az ember, Anthropo-geographia vagy a földrajz történeti alkalmazásának alapvonalai, Budapest 1887, 332-359; Hermann HAACK - Max Georg SCHMIDT, Geopolitscher Typen-Atlas zur Einführung in die Grundbegriffe der Geopolitik, Gotha 1929, 15-30; Walther VOGEL, Rhein und Donau als Staatenbilder I-II, in: Zeitschrift für Geopolitik, 1, 1924, 2, 63-73, and 3, 135-147.

5 HAACK - SCHMIDT, 51-53. 
the Monarchy lost its Italian provinces in the late $19^{\text {th }}$ century, two decades later it acquired Bosnia-Herzegovina.

The last territorial change within the Austro-Hungarian Monarchy took place in the last year of the First World War. In May 1918, the Monarchy signed a peace treaty with Romania in Bucharest. As a result, an area of $5,636 \mathrm{~km}^{2}$ was annexed to the Monarchy (a strip with a width of 3-16 kilometres at the eastern and southern feet of the Carpathian Mountains and at the eastern border of Bukovina). ${ }^{6}$ These territorial changes can be explained by the intention of providing improved conditions for guarding the Monarchy's borders. By annexing Bosnia and Herzegovina, the Monarchy's very long borders originally running through Croatia, Slavonia and Dalmatia got considerably - by hundreds of kilometres - shortened. The terms of the Peace Treaty of Bucharest also included the establishment of a better defence system in the Carpathian region. ${ }^{7}$ As it is attested by the formerly described two territorial changes (the annexation of Bosnia-Herzegovina and the changes described in the Peace Treaty of Bucharest), in the first years of the $20^{\text {th }}$ century the Monarchy, one of Europe's great powers, concentrated its powers and energy on the Balkans and the Eastern half of Europe.

At the same time, parallel with the formerly detailed shift to the East, another spatial phenomenon could be detected in Europe. This change, the movement of Europe's 'historical line', contradicted the formerly described tendency, observable within the Habsburg Empire. ${ }^{8}$ As it is defined in geopolitics and political geography, a historical line is a geographically describable spatial line, along which main historical events take place and where societies and countries turn to. In Europe, this line had been located in the Mediterranean region before the American continent was discovered. When the New World was discovered and conquered in 1492, this line moved to Europe's Atlantic Coast, meaning, that all of a sudden the formerly peripheral countries of Spain and Portugal moved into the centre of the world of that time. With this change a new period started, which was marked by Spain and Portugal as great sea powers. The nations of the European cultural community aimed to get to the Atlantic Coast that symbolized for them access to wealth and power. These countries occasionally had to pay very high prices due to the wars they fought with each other. At the same time, the Mediterranean Basin was becoming less and less significant.

All these spatial factors resulted in the movement of the continent's historical line from the south and southeast to the west and northwest, while the areas within the Habsburg Empire and the Austro-Hungarian Monarchy shifted, as we have seen, to the east. All these changes meant that the Austro-Hungarian Monarchy, by moving away from the Atlantic Ocean, also distanced itself from Europe's major historical line. ${ }^{9}$

6 László GULYÁS, A térdre kényszerített Románia. A bukaresti béke 1918, in: Nagymagyarország, 4, 2012, 4, 41-51.

7 Mihály Miklós NAGY, Trianon földrajzi előzménye - Az első világháború geostratégiai (katonaföldrajzi) viszonyrendszere, in: Közép-Európai Közlemények. Történészek, geográfusok és regionalisták folyóirata 3, 2010, 4, 34-43.

8 HAACK - SCHMIDT, 53-55.

9 Norbert PAP, Political geography of Southern Europe, in: Geografski Vestnik, 75, 2013, 2, 101-109; Norbert PAP, Hungary, the Balkans and the Mediterranean, Pécs 2013, 212. 


\section{Criteria for a Nation's Great Power Status, or is Diversity an Advantage?}

There are clearly identifiable criteria for determining a nation's great power status (including size, population, military power etc.). ${ }^{10}$ Our paper aims to offer a brief survey of these indicators in relation to the Austro-Hungarian Monarchy.

In the period of the foundation of the Austro-Hungarian Monarchy (1867), its area was $624,231 \mathrm{~km}^{2}$ which grew to $676,333 \mathrm{~km}^{2}$ when Bosnia and Herzegovina were annexed. It meant that by its size the Monarchy was the third largest state in Europe at the end of the $19^{\text {th }}$ century after Russia and the unified state of Norway and Sweden. In addition, from 1905 onwards, when the union of Norway and Sweden ceased to exist, the Austro-Hungarian Monarchy became Europe's second largest state. ${ }^{11}$ Considering the number of its population, the Monarchy also belonged to Europe's most populous countries. In 1913, its population reached 51,000,000, and it was only Russia $(159,000,000)$ and Germany $(64.5$ million) that preceded the Monarchy in Europe. (See Table 1).

TABLE 1: Population of European Great Powers in 1910

\begin{tabular}{|l|l|}
\hline State & million \\
\hline Russia & 159.3 \\
\hline Germany & 64.5 \\
\hline Austro-Hungarian Monarchy & 50.8 \\
\hline France & 39.5 \\
\hline Great Britain & 44.9 \\
\hline Italy & 34.4 \\
\hline
\end{tabular}

Source: KENNEDY, 190.

In terms of military power, the Monarchy lagged somewhat behind, especially when the military power of Russia was considered. (See Table 2).

TABLE 2: Military force of European Great Powers in 1910

\begin{tabular}{|l|l|}
\hline State & number \\
\hline Russia & $1.352,000$ \\
\hline France & 910,000 \\
\hline Germany & 891,000 \\
\hline Great Britain & 532,000 \\
\hline Austro-Hungarian Monarchy & 444,000 \\
\hline Italy & 345,000 \\
\hline
\end{tabular}

Source: KENNEDY, 195.

10 KENNEDY, 13-22.

11 Ferenc SZÁVAI, A kettős monarchia öröksége, Szekszárd 2000, 18. 
The Monarchy's military power was still significant when considering Europe's great powers. As it can be seen from the figures, the Monarchy met the criteria for a great power status. In our opinion, though, due to the political geographical, and physical geographical diversity of the country, the major trends moved the country to the opposite direction.

\section{TABLE 3: Ethnic diversification of Austro-Hungarian Monarchy in 1910}

\begin{tabular}{|l|l|}
\hline Nations & Proportion \% \\
\hline Germanic & 23.7 \\
\hline Hungarian & 19.8 \\
\hline Czech & 12.7 \\
\hline Polish & 9.8 \\
\hline Ruthenian and Ukrainian & 7.9 \\
\hline Rumanian & 6.4 \\
\hline Croatian & 5.8 \\
\hline Serb & 4.0 \\
\hline Slovak & 3.9 \\
\hline Slovenian & 2.5 \\
\hline Italian & 1.5 \\
\hline Bosnian & 1.2 \\
\hline Others & 0.8 \\
\hline All & 100.0 \\
\hline
\end{tabular}

Source: GULYÁS, 170.

When considering the political geographical factors, from Table 3 it can clearly be concluded that 51 million inhabitants of the Monarchy ethnically represented an enormous heterogeneity. None of its ethnicities reached $50 \%$ of its overall population, what is more, not even $25 \%$ of it. ${ }^{12}$ Ethnic dividedness led to the complicated structure of the country's constitutional law. ${ }^{13}$ From the point of view of constitutional law and administration, the Austro-Hungarian Monarchy comprised the three large areas of Austria, Hungary and the jointly administered Bosnia-Herzegovina. ${ }^{14}$

12 László GULYÁS, Az Osztrák-Magyar-Monarchia és a regionális etnikai nacionalizmus, in: Pécsi Tudományegyetem Regionális politika és gazdaságtan Doktori Iskolájának Évkönyve, László GAZDAG (ed.), Pécs 2002, $168-188$.

13 Zoltán HAJDÚ, Az Osztrák-Magyar Monarchia Európában a 19-20. század fordulóján, in: Magyarország történeti földrajza I, Pál BELUSZKY (ed.), Budapest - Pécs 2005, 41-69.

14 József ZACHAR, Osztrák-Magyar Monarchia, in: Magyarország az első világháborúban, Lexikon A-Zs, Jolán Szijj (ed.), Budapest 2000, 523. 


\section{The provinces of Austria (Austrian Empire) can be grouped as follow:}

- Hereditary provinces (Lower Austria, Upper Austria, Karinthia, Kraina, Salzburg, Steiermark, Tirol, Vorarlberg),

- The Czech provinces of Czechia, Moravia, Silesia.

- Eastern territories (Bukovina, Galicia and Lodomeria),

- Dalmatia and three seaside provinces (Görz-Gradiska, Istria, Trieste with the area of Cattaro).

\section{Hungary (The Kingdom of Hungary) comprised three parts: ${ }^{15}$}

- The Kingdom of Hungary,

- Croatia-Slavonia,

- The Town of Fiume and its environs. ${ }^{16}$

\section{Bosnia-Herzegovina, which was first occupied in 1878, then annexed in 1908.}

It can be seen from the above that the administrative structure of the Monarchy was politically very complicated. This situation was made worse by the fact that the majority of the Monarchy's provinces could be found in Central Europe, but when Bosnia-Herzegovina was annexed, in addition the area of the Monarchy comprised part of the Balkans, while Bukovina, Galicia and Lodomeria demonstrated Eastern European characteristics.

The physical geographical features of the Monarchy were also very complex. The area of the country included the high peaks of the Alpine region, the relatively closed blocks of the Czech-Forest, Erzgebirge, the Sudeten Mountains, the Carpathian and the Dinari ranges, areas of Great Plains as well as the typical seaside areas of Dalmatia. Unifying this diversity and having it function as one state was to some extent due to the compelling effects of geographical factors, but it rather depended on the complicated and always changing power structure of Europe in the Modern Era.

The point of view of Jenő Cholnoky (1870-1950), one of Hungary's most notable contemporary geographers, is of considerable significance in this respect. In one of his books, published after the fall of the Monarchy, he called the state a 'compound of geographical waste'. ${ }^{17}$ We think that there was some truth in his negative opinion, since the Monarchy was made up of too many, too diverse and too differing regions.

Despite all the formerly described negative aspects, the Monarchy was still viable in the opinion of Jenő Cholnoky because, according to him, it was organized around Hungary, a country, located in the Carpathian Basin. Both Hungarian and foreign geographers, including Karl Haushofer, a well-known specialist of geopolitics, generally prove this point by using a simple map.

15 VIZI, Magyarország, 263-265.

16 Tamás László VIZI, Illíria a francia nagyhatalmi politikában a 19. század elején, in: Közép-Európai Közlemények. Történészek, geográfusok és regionalisták folyóirata 4, 2011, 2, 7-20.

17 Jenő CHOLNOKY, A Föld és élete, Világrészek, országok, emberek I, Budapest 1936, 121. Karl HAUSHOFER, Grenzen, In ihrer geopolitischen und politischen Bedeutung, Heildelberg - Berlin - Magdeburg $1939,141$. 


\section{Map 1. The area of the Austro-Hungarian Monarchy without Hungary}

Source: CHOLNOKY, 121.

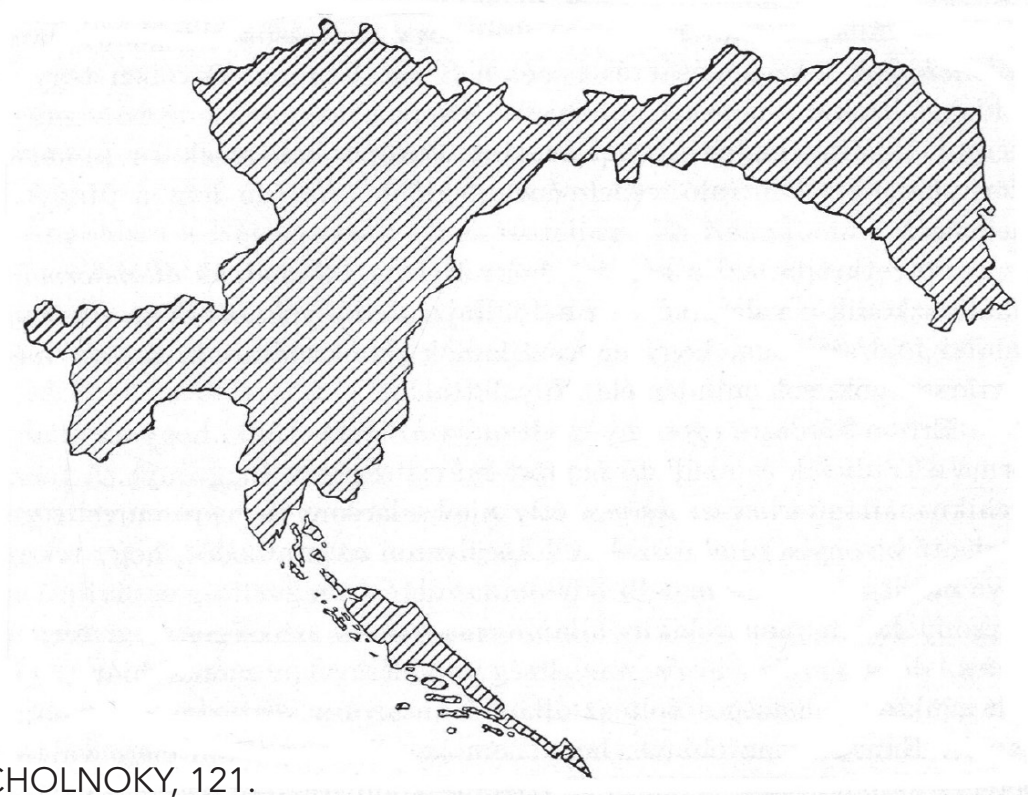

When reading the map, it can be seen that the outer borders of the Monarchy are indicated in it but Hungary is not part of it. In Cholnoky's opinion, the area of the state without Hungary is amorphous and fragmented; thus it demonstrates that Hungary played a central role within the Austro-Hungarian Monarchy.

In our opinion, although the map proves that the existence of the Austro-Hungarian Monarchy was unimaginable without Hungary, Cholnoky overemphasized Hungary's central role. It is also part of the truth that there were centrally positioned areas within the other provinces as well. Within the Monarchy, the Czech Basin and the Vienna Basin had several cities of utmost geographical importance in them, including Prague and Vienna. Consequently, the Austro-Hungarian Monarchy surrounded core areas of three basins as well as areas along and near the Danube (e.g. Galicia and Vorarlberg on the other side).

Vienna was the economic, administrative and financial centre of the Monarchy, while its three most important port cities included Trieste, Pula and the Hungarian Fiume. It was also one of the favourable features enhancing the geographical potential of the Monarchy that the country had several hundreds of kilometres of coastline in the seaside areas, in Dalmatia, Croatia and Slavonia, although the sea the Monarchy had access was the Adriatic, only an arm of the Mediterranean Sea.

In summary of the above, it can be stated that the Monarchy was characterized by diversity concerning the ethnicity and religion of its population, and also when considering the culture and the state of development of its individual regions. The unification of this variety of ethnicities and areas within one state resulted in a unique political and geographical conglomerate. 


\section{The Problem of the Failure of Colonization}

At the turn of the 1860s and 1870s, the leading European countries were the true great powers of the world. (The United States at that time still suffered from the aftermath of the Civil War of 1861-1865, while Japan showed only the first signs of modernization). In Europe, due to the French-Prussian War of 1870-1871, France got considerably weakened and thus was forced to give up its political ambitions for a while. Consequently, European affairs mostly depended on the politicians of a unified Germany, Russia, England, and the Austro-Hungarian Monarchy. ${ }^{18}$

After a few decades, at the onset of a new period of colonization, the Austro-Hungarian Monarchy was already at a disadvantage. While new colonial empires came into being, the Monarchy intentionally distanced itself from the process of colonization. This disadvantage was further deepened by the fact that in this period countries were ranked by the size of their areas and population and the number and size of their colonies. Considering the figures of 1910, it can be seen that the British Empire had 351 million inhabitants and the population figures in France and its colonies nearly reached 40 million. Even Holland, a country of less political significance had 39 million inhabitants, Belgium 19 million in their colonies. ${ }^{19}$

Formerly, the Habsburg Empire by the Danube also had attempted to expand overseas. Austrian and Hungarian historians ${ }^{20}$ usually mention three events to support this idea. ${ }^{21}$ The first event was the establishment of the Ostend Society, which, when the Monarchy lost the southern part of Holland, was replaced by the East-India Trade Society of Trieste. In the last years of the reign of Empress Maria Theresa, it was this Society that launched an expedition and secured the colony of Nicobar Islands in the Far East for the Habsburgs. After a few years, this colony was unfortunately lost.

The second venture of significance was related to the period of the Napoleonic Wars. In this period, the Viennese court arranged the marriage of Archduchess Leopoldina (1797-1826) to the crown prince of Portugal. When, fleeing from the French military, the Portuguese court moved to Brazil, a Portuguese colony at that time, Leopoldina and her husband proclaimed the independent Empire of Brazil. This event offered the Monarchy a new opportunity to expand overseas but the Habsburgs again did not want to - and partly owing to Leopoldina's premature death - were not able to seize the opportunity. ${ }^{22}$

The third occasion is related to the period preceding the Austro-Hungarian Compromise of 1867. The younger brother of Emperor Francis Joseph, Archduke Maximilian (1832-1867) got to Mexico with the support of the French. He was soon crowned to be the Emperor of Mexico. But, owing to changes in Europe, the French troops were soon withdrawn from the country. Maximilian, involved in a meaningless civil war with the locals, was soon caught

18 István DIÓSZEGI, A Ferenc József-i kor nagyhatalmi politikája, Budapest 1987, 5-10.

19 Révai Nagy Lexikona, IX. kötet. Révai Testvérek Irodalmi Intézet Rt, Budapest 1913, 134-135.

20 Mihály Miklós NAGY, Egy elmulasztott történelmi lehetőség: az osztrák-magyar gyarmatosítás, in: Közép-Európai Közlemények. Történészek, geográfusok és regionalisták folyóirata 3, 2010, 3, 46-57.

21 Manfred RAGG, Oesterreich-Ungarn als Kolonialmacht, Leipzig 1911; Leo WESSELY, Eine kolonie für Österreich-Ungarn, Warnsdorf 1918.

22 Brigitte HAMANN, Habsburg lexikon, Budapest 1990, 239-241. 
by the rebels and executed in 1867. The year of Maximilian's death is a speaking date. It was the year when the Compromise between Austria and Hungary was signed, but this is also the date when the Habsburgs gave up on their last attempt to expand their empire overseas.

The reason for this was not known even to contemporaries; it is difficult to interpret in our time as well. Dalmatia was part of the Monarchy, so the Habsburgs were gradually developing their naval forces. Their Navy, although not the strongest, was in the forefront of the world. ${ }^{23}$ Under the dualist system, the individual ships and the fleet of the joint Navy represented the political and commercial interests of the Monarchy at the world's seas. In addition, the Navy was involved in oceanographic, geographical and ethnographic expeditions as well. There were over 80 missions to faraway destinations (outside the Mediterranean Basin), which were all of great significance. ${ }^{24}$

The failure of colonization was probably due to the inadequacy of the Monarchy's social potential. In our opinion, the lack of overseas colonies presumably led to the fact that the Monarchy was falling behind in the rivalry of great powers. This tendency can be proven by figures: the Monarchy did not possess colonies, consequently, it had no colonial army. Britain at the same time had a British-Indian army of 1,440,000.25

\section{Conclusion}

Our survey aimed to contribute to the clarification of the causes of the fall of the Austro-Hungarian Monarchy by exploring three specific issues.

First, it was introduced how the Habsburg Empire gradually shifted to the East. The conclusion of this issue can best be formulated as a question. Can a state be one of the European great powers which is gradually moving away from the historical line?26

Second, the topic of diversity was considered. It was shown that the Monarchy met several criteria which could have made it a true great power. In other words, it can be concluded that the Monarchy disposed of favourable natural and social potentials. But all these positive criteria (e.g. high population figures) went together with a negative feature, which reduced their original value (e.g. the ethnic diversity of the population). In order to explore the former example further, we can say that although the Monarchy was one of Europe's most populous states, the ethnic diversity made it impossible for the state to play an accordingly significant role in European foreign policy. The nations living within the Monarchy - within parliamentarism, typical of the age - always tried to assert their own interests. This feature prevented the Austro-Hungarian Monarchy from becoming one of the true great powers in Europe.

23 Károly CSONKARÉTI, A császári és királyi haditengerészet és a Magyar Királyság, in: Hadtörténelmi Közlemények. Történészek, geográfusok és regionalisták folyóirata 31, 1984, 2, 203-255.

24 Mihály Miklós NAGY, Boldog békeidők haditengerészei, A k.u.k. hadiflotta utazástörténete, Budapest 2003, 32-56, 407-412; Horst Friedrich Mayer - Dieter Winkler, Rot-Weiss-Rote Weltreisen: Expeditionen der k. k. Marine, Wien 1998, 33-109, 134-172.

25 Walter KLEINDEL, Der Erste Weltkrieg, Daten-Zahlen-Fakten, Wien 1989, 28.

26 Mihály Miklós NAGY, Az Osztrák-Magyar Monarchia geostratégiai és katonaföldrajzi kényszerei, in: Közép-Európai Közlemények. Történészek, geográfusok és regionalisták folyóirata 2, 2009, 2-3, 31-40. 
Further, one of the subtopics of this question, the failure of colonization was investigated. The conclusion is that by intentionally distancing itself from the colonization processes, the Austro-Hungarian Monarchy deprived itself from significant resources.

In summary, it can be stated that the state of the Austro-Hungarian Monarchy was characterized by diversity from the point of view of physical and political geography as well. The country was further divided by the particular interests of its nations and the conflicting interests of its people, which were sometimes real, sometimes alleged or, occasionally, intentionally deepened. Considering all the above, one of the causes of the dissolution of the Monarchy was the fact that it emerged in an age and strived to function as one of the great multiethnic powers when all the other European states tried to strengthen their role as nation-states. From this point of view, the Monarchy was a unique creation.

\section{Abstract}

During the period of over 50 years of its history (1867-1918), the Austro-Hungarian Monarchy played a significant role in power politics in the world and primarily in Europe. Considering its geographical features, i.e. its size and population figures, the Austro-Hungarian Monarchy was viewed as one of the world great powers. ${ }^{27}$ This function came to an end abruptly when the Empire dissolved in 1918. Central European and Hungarian historians have for long been arguing about the reasons and causes of the dissolution of the Monarchy. ${ }^{28}$ This paper aims to contribute to this academic dispute by throwing light on several specific historical-geographical and political-geographical aspects of the event.

This paper investigates the above issue from three different points of view. On the one hand, it examines how the Empire in a geographical sense shifted to the East. On the other hand, it offers an insight into the ethnic and cultural diversity of the Monarchy. Finally, the paper aims to analyze the Monarchy's failed attempt at colonization.

\section{Keywords}

Habsburg dynasty, history of Austro-Hungarian Monarchy, dissolution of the Monarchy, colonization 